\title{
FACTORS AFFECTING THE INTENTION TO PURCHASE ORGANIC VEGETABLES WITH THEORY PLANNED BEHAVIOUR APPROACH
}

\author{
Septiadinur Rejeki ${ }^{*}$, Novil Dedy Andriatmoko², Hery Toiba ${ }^{2}$ \\ ${ }^{1}$ Undergraduate Agribusiness Study Program, Agricultural Socio-Economics Departement, Brawijaya University, \\ Indonesia \\ ${ }^{2}$ Agricultural Socio-Economics Departement, Brawijaya University, Indonesia \\ *corresponding author: septiadinurr@ student.ub.ac.id
}

\begin{abstract}
The recent modern healthy lifestyle is influenced by the selection of food ingredient such as organic vegetables. Organic vegetables are well known in community. But, the purchase of organic vegetables has decreased in the last few years because price has been high, packaging and quality have not been interesting, and low priority on organic vegetables than conventional vegetables. This research was conducted by the Theory Planned Behaviour (TPB) approach with 6 variables. Those are price, packaging, quality, attitude, subjective norms, and perceived behavioral control to analyze the effect of factor to the decreased purchase attitude and intention buy organic vegetables with Structural Equation Model (SEM)-Partial Least Square (PLS) analysis. The results showed that the following factors are price, quality, attitude, subjective norms, and perceived behavioral control have an effect to the decreased purchase attitude and intention buy organic vegetables. So, it can be a strategy for selling and consuming organic vegetables in the future.
\end{abstract}

Keywords: Organic Vegetables, Structural Equation Model, Theory Planned Behaviour.

\section{INTRODUCTION}

One of the factors that influence the current modern healthy lifestyle is daily food. Some people are selective in choosing food ingredients that can provide good benefits for the body. The community applies the application of free food with safe conditions and from chemical residues called organic. According to (Pawlewicz, 2020) organic products are part of a modern healthy lifestyle. Consumers of organic products, including organic vegetables, tend to be selective in determining purchases. Most of the people who know organic vegetables. Organic vegetables are products that have advantages with an antioxidant content of 1050 percent which can prevent disease in the body compared to inorganic vegetables (Alfian, 2016).
According to the IPB Southeast Asian Food and Agriculture Science an Technology (SEAFAST) Center in (Liputan6, 2018) around 2014, data on Indonesian people's vegetable consumption increased to reach 180 grams per capita per day. Meanwhile, around 2016 in (BPS et al., 2017) the consumption of vegetables in Indonesia has decreased to reach 173 grams per capita per day. The range of the two consumption data is still far from the angka kecukupan gizi (AKG) which is not the WHO standard of around 250 grams of vegetables. However, according to organic vegetable marketer "Ijo-Ijo" in Kelurahan Sawojajar Malang City, consumers have increased in buying organic vegetables by around $15-25 \mathrm{~kg}$ or 60-90 bunches of organic per day during the last few months whereas several years ago the demand for organic vegetables was more than $40 \mathrm{~kg}$ or 150

CITATION: Rejeki, S., Toiba, H., Andriatmoko, N., D., (2021). Factors Affecting the Intention to Purchase Organic Vegetables with Theory Planned Behaviour Approach, Agricultural Socio-Economics Journal, 21(2), 103-110 DOI: http://dx.doi.org/10.21776/ub.agrise.2021.021.2.3 
bunches per day. However, the amount of consumption of organic vegetables does not include demand from outside Malang. This shows that the decline in consumers buying organic vegetables around Malang City tends to have a market segment in organic vegetable consumers.

The reasons for the decline in organic vegetable consumers stem from price, quality, and packaging. One of the most common problems in society is the higher price of organic vegetables. According to (Paradiba et al., 2017) some farmers sell most of their organic vegetable yields in conventional markets because farmers find it difficult to sell organic vegetables at higher competitive prices. In addition, several studies (Andari, 2016); (Paradiba et al., 2017); (Hasan et al., 2019) stated that many consumers consider the low quality of vegetables, the lack of uniformity in the form of vegetables, the packaging of vegetables which are mostly made of plastic which can damage the environment, the appearance that is not fresh, the limited variety of organic vegetables available, and consumers buy vegetables for consumption by infants, toddlers, elderly or sick people only while healthy adults are quite conventional vegetables.

This investigation is important because currently many people already know about vegetables but there are several factors that have led to decreased purchase intentions and are supported by consumers who are still few who make organic purchases. This study aims to analyze the factors of decreased attitudes and purchase intentions of organic vegetables by applying Theory Planned Behavior (TPB).

\section{RESEARCH METHODS}

This research uses a quantitative approach, which is a method for testing certain theories by examining the relationship between variables in the study. The research location was in the DapurQoe (vegetable and fruit shop) on Jalan Danau Bratan Raya C3 A12, Sawojajar Village, Kedungkandang District, Malang City, East Java which was can purposively or deliberately. The research was conducted on February 1-29, 2020.

The sample used in this study were female respondents. The sampling technique used is nonprobability sampling with accidental sampling method, which is purposely taking the sample to meet the researcher and willing to be the respondent. The number of samples used in this study were about 70 respondents.
This study used two types of data consisting of primary data obtained directly by distributing questionnaires and from interviews with organic vegetable consumers, especially housewives based on the questions in the questionnaire. Then secondary data obtained from production data and demand for organic vegetables in the Sawojajar village area and literature related to this research.

Data collection techniques used in this study consisted of interviews, observation and documentation. Meanwhile, the data analysis technique used in this research is descriptive analysis and Structural Equation Model (SEM) Partial Least Square (PLS) WarpPLS 7.0 software. According to (Solimun et al., 2017), there are two SEM-PLS measurement models used, namely the structural model or inner model to describe the relationship that occurs between latent variables. The following is the inner model equation.

$\mathrm{H} 1=\gamma 1 \xi 1+\gamma 2 \xi 2+\gamma 3 \xi 3+\zeta 1$

$\eta 2=\beta 1 \eta 1+\gamma 4 \xi 4+\gamma 5 \xi 5+\zeta 2$

Information:

$\eta 1=$ Attitude variable

$\eta 2=$ Purchase intention variable

$\gamma 1=$ Coefficient of price variable

$\gamma 2=$ Coefficient of packaging variable

$\gamma 3=$ Coefficient of quality variable

$\gamma 4=$ Coefficient of subjective norm variable

$\gamma 5=$ Coefficient of perceived behavioral control variable

$\xi 1=$ Price variable

$\xi 2=$ Packaging variable

$\xi 3=$ Quality variable

$\xi 4=$ Subjective norm variable

$\xi 5=$ Perceived behavioral control variable

$\beta 1=$ Coefficient of variable attitude

$\zeta 1-2=$ Error in model

The two measurement models or outer models are used to describe the relationship that occurs between latent variables and their indicators. The following is the equation for the outer model.

1. Exogenous Latent Variables
$\times 1.1=\lambda \times 1.1 \xi 1+\delta 1$
$\times 1.2=\lambda \times 1.2 \xi 1+\delta 2$
$\times 2.1=\lambda \times 2.1 \xi 2+\delta 3$
$\times 2.2=\lambda \times 2.2 \xi 2+\delta 4$
$\times 2.3=\lambda \times 2.3 \xi 2+\delta 5$
$\times 3.1=\lambda \times 3.1 \xi 3+\delta 6$
$\times 3.2=\lambda \times 3.2 \xi 3+\delta 7$
$\times 3.3=\lambda \times 3.3 \xi 3+\delta 8$


$\mathrm{x} 4.1=\lambda \times 4.1 \xi 4+\delta 9$

$\mathrm{x} 4.2=\lambda \times 4.2 \xi 4+\delta 10$

$\mathrm{x} 4.3=\lambda \times 4.3 \xi 4+\delta 11$

$\mathrm{x} 5.1=\lambda \times 5.1 \xi 5+\delta 12$

$\mathrm{x} 5.2=\lambda \times 5.2 \xi 5+\delta 13$

2. Endogenous Latent Variables

$\mathrm{y} 1.1=\lambda \mathrm{y} 1.1 \eta 1+\varepsilon 1$

$\mathrm{y} 1.2=\lambda \mathrm{y} 1.2 \eta 1+\varepsilon 2$

$\mathrm{y} 1.3=\lambda \mathrm{y} 1.3 \eta 1+\varepsilon 3$

$\mathrm{y} 2.1=\lambda \mathrm{y} 2.1 \eta 1+\varepsilon 4$

$\mathrm{y} 2.2=\lambda \mathrm{y} 2.2 \eta 1+\varepsilon 5$

$\mathrm{y} 2.3=\lambda \mathrm{y} 2.3 \eta 1+\varepsilon 6$

Information:

$\mathrm{x} 1.1-1.2=$ Indicator of price variable

$\mathrm{x} 2.1-2.3=$ Indicator of packaging variable

$\mathrm{x} 3.1-3.3=$ Indicators of quality variables

$\mathrm{x} 4.1-4.3=$ Indicators of subjective norm variables

x5.1-5.3 = Indicator of perceived behavioral control variable

y1.1-1.3 = Indicator of attitude variable

y2.1-2.3 = Indicator of intention variable

$\lambda \times 1.1-1.2=$ Coefficient of price variable indicator

$\lambda \times 2.1-2.3=$ Coefficient of packaging variable indicator

$\lambda \times 3.1-3.3=$ Coefficient of quality variable indicator

$\lambda \times 4.1-4.3=$ Coefficient of subjective norm variable indicator

$\lambda \times 5.1-5.3=$ Coefficient of perceived behavioral control variable indicator

גy1.1-1.3 = Coefficient of attitude variable indicator

גy2.1-2.3 = Coefficient of intention variable indicator

$\xi 1=$ Price variable

$\xi 2=$ Packaging variable

$\xi 3=$ Quality variable

$\xi 4=$ Subjective norm variable

$\xi 5=$ Perceived behavior control variable

$\eta 1=$ Attitude variable

$\eta 2=$ Intention variable

$\delta 1-14=$ Exogenous latent variable indicator error

ع1-6 = Endogenous latent variable indicator error

After measuring the two models, then making a path diagram or path.

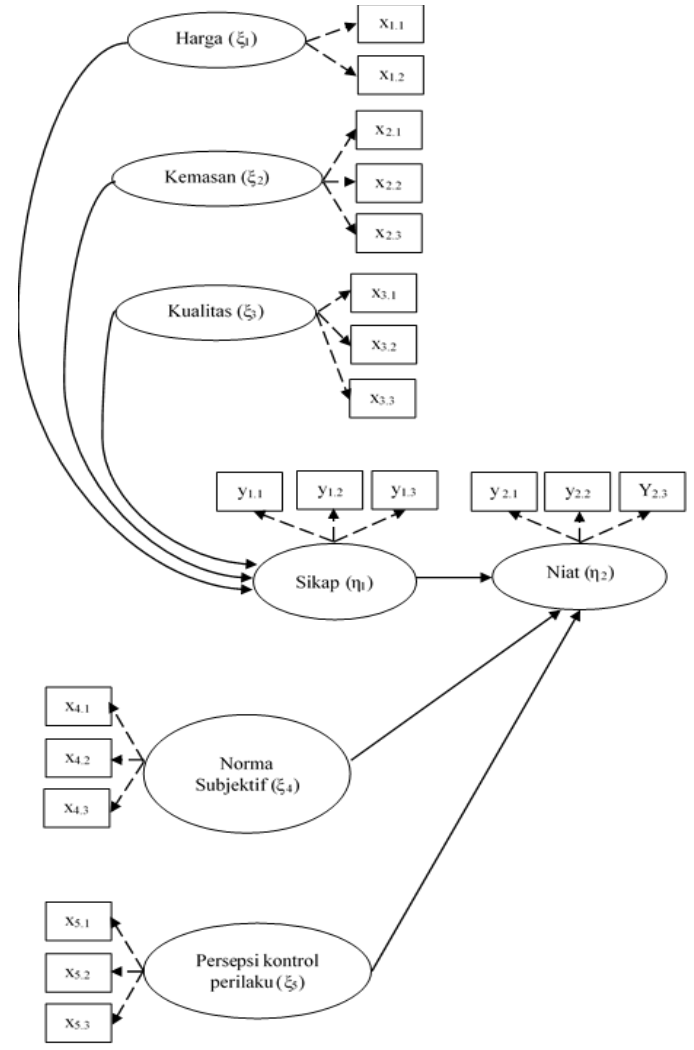

Figure 1. Research Path Diagram

Information:

$\begin{aligned} \longrightarrow \quad= & \text { The effect relation between latent } \\ & \text { variables } \\ = & \text { The relation between latent variables } \\ & \text { and indicators } \\ \xi 1-5 \quad & \text { Exogenous latent variables (price, } \\ & \text { packaging, quality, subjective norms, } \\ & \text { perceived behavioral control) } \\ = & \text { Endogenous latent variable (attitude, } \\ & \text { intention) } \\ \eta 1 & \text { Indicator of exogenous latent variables } \\ \mathrm{x} 1.1-\mathrm{x} 5.3= & \text { Indicator of endogenous latent } \\ \text { y1.1-y2.3 } & \text { variables }\end{aligned}$

Then the estimation of the outer model uses the PLS Regression type algorithm analysis and the inner model uses the Warp3 type algorithm analysis. Next, the evaluation of the two models, namely the first measurement model to test the effect of indicators on latent variables consisting of several criteria are convergent validity (factor loading $\geq 0,5)$; discriminant validity $(\sqrt{\mathrm{AVE}}>$ the correlation value between variables); and reliability test are composite reliability (acceptable if $\geq 0,70$ ) and alpha cronbach (acceptable if $\geq 0,70$ ).

The two structural models to test the effect of exogenous latent variables on endogenous latent variables which consist of several criteria are $\mathrm{R}$ 
Square (R square $\leq 0.25$ weak, $\leq 0.45$ moderate, and $\leq 0.70$ strong), Q Square ( $\geq 0$ good validity), full collinearity VIF $(\leq 3.3)$, effect size (weak $>0.02$, medium $>0.15$ and strong $>0.35$ ), and Goodness of Fit $(\mathrm{GoF})$ are:

Table 1. Goodness of Fit Criteria

\begin{tabular}{cc}
\hline Model Fit and Quality Indices & Rule of Thumb \\
\hline Average Path Coefficient & p-value $\leq 0,05$ \\
(APC) & p-value $\leq 0,05$ \\
Average R-squared (ARS) & -valued \\
Average Adjusted R-squared & p-value $\leq 0,05$ \\
(AARS) & acceptable if \\
Average Block Variance & $\leq 3,3$ \\
Inflation Factor (AVIF) & acceptable if \\
Average Full Collinearity & $\leq 3,3$ \\
Variance Inflation Factor & $\geq 0,1=$ small \\
(AFVIF) & $0,25=$ medium \\
& $\geq 0,36=$ large \\
Tenenhaus GoF (GoF) & acceptable if \\
Sympson's Paradox Ratio & $\geq 0,70$ \\
(SPR) & acceptable if \\
R-squared Contribution Ratio & $\geq 0,90$ \\
(RSCR) & acceptable if \\
Statistical Suppression Ratio & $\geq 0,70$ \\
(SSR) & acceptable if \\
Nonliniear Bivariate & $\geq 0,70$ \\
Causality Direction Ratio & \\
(NLBCDR) &
\end{tabular}

Finally, hypothesis testing can be seen from the path diagram at a p-value less than 0.05 , which is a significant result so that the hypothesis is accepted. The resampling method in WarpPLS 7.0 software is Stable3.

\section{RESULTS AND DISCUSSION}

The criteria for the selected respondents were female as a housewife who is a consumer of organic vegetables at the DapurQoe (vegetable and fruit shop) in Sawojajar Village. Based on data collection, it was found that the age characteristics of the respondents were at most 26-35 years (early adulthood) as many as 27 people. The fact in the research place is that the age range on average is married and has the latest information. The majority of respondents work as housewives around $39 \%$ (27 people). The average education level of the respondents is S1 as many as 36 people $(51 \%)$. Respondents had the most dominant income, amounting to Rp. 2,500,000-Rp. 4,000,000 as many as 29 people (41\%). Meanwhile, the types of vegetables that were often consumed by respondents were spinach, around $47 \%$ as many as 33 people. The frequency of purchasing organic vegetables is very diverse, consumers who make the most purchases once a week are around 54\% (38 people).

The first stage, the results of the evaluation of the measurement model of this study on convergent validity, namely the variable has a loading factor value of more than 0.05 and a pvalue of less than 0.001 . Based on the results of the data in table 6 , it can be seen that all variables in this study meet the criteria for testing the convergent validity and are said to be valid. A questionnaire is said to be valid if the Average Variance Extracted (AVE) value is greater than the correlation between variables in the same column. Value $0.866 ; 0.804 ; 0.815 ; 0.837 ; 0.859 ; 0.893$; and 0.851 is the result of the AVE value. While all these values are greater than the correlation value between other variables, all indicators meet the criteria for discriminant validity testing and can be explained properly.

The reliability test shows that the results of all composite reliability values are greater than the specified standard value is 0.7 . So each of each variable in the questionnaire in this study is included at a good reliable level. Meanwhile, the Cronbach's alpha value is also greater than the specified standard value, which is 0.6 , which means that the overall variables in the questionnaire are good reliability. In conclusion, a questionnaire with several variables with indicators can be used in this study.

The results of the evaluation of the structural model of the study show the results of the path diagram (Figure 2).

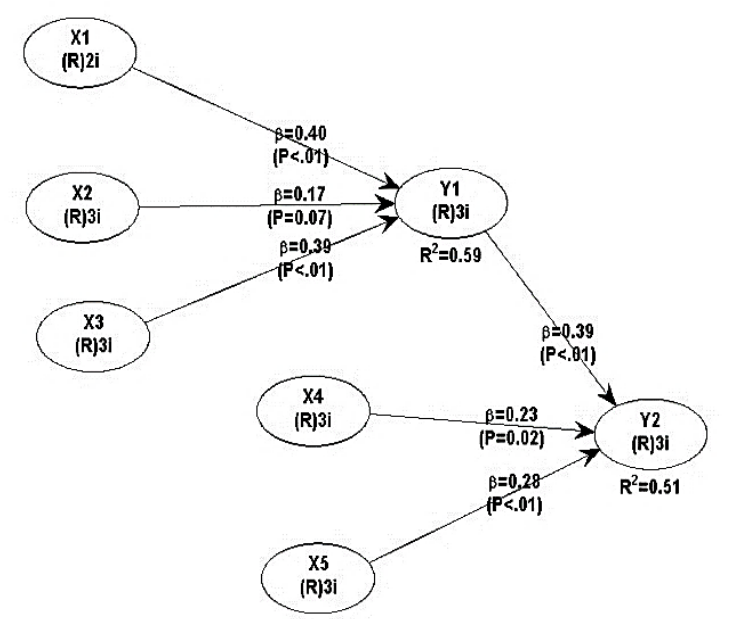

Figure 2. Path Diagram Results.

In the results of $\mathrm{R}$ Square, it was obtained an attitude of 0.594 , meaning that the variance of attitude could be explained by $59.4 \%$ by the variance of price, packaging and quality. For the $\mathrm{R}$ Square value of intention 0.506 means that the variation of intention can be explained by $50.6 \%$ by 
variations in attitudes, subjective norms and perceived of behavioral control. While the results of Q Square attitude 0.586 and intention 0.504 greater than 0 means good predictive validity. Full collinearity VIF shows all values less than 3.3, meaning that the model is free from the problem of vertical, lateral multicollinearity and commod method bias. The value of the effect size variable on price, quality, subjective norms, perceived behavior control exceeds 0.15 including the criteria for medium. Packaging and attitude variables have an effect size value less than $\geq 0.02$, including weak criteria. So some variables are classified as medium criteria. To evaluate goodness of fit $(\mathrm{GoF})$ all criteria are met, accepted and in accordance with predetermined standard values. Then this research model fulfills the criteria and can be accepted.

Table 2. Hypothesis Testing Results.

\begin{tabular}{lcc}
\hline \multicolumn{1}{c}{ Hypothesis } & $\begin{array}{c}\text { Path } \\
\text { Coefficient }\end{array}$ & $\begin{array}{c}\text { P } \\
\text { Value }\end{array}$ \\
\hline $\begin{array}{l}\text { H1: Price effects the low } \\
\text { purchasing attitude of } \\
\text { organic vegetables }\end{array}$ & 0,40 & $<0,01$ \\
$\begin{array}{l}\text { H2: Packaging effects the } \\
\text { low purchasing attitude of } \\
\text { organic vegetables }\end{array}$ & 0,17 & 0,07 \\
$\begin{array}{l}\text { H3: Quality affects the low } \\
\text { purchasing attitude of } \\
\text { organic vegetables }\end{array}$ & 0,39 & \\
$\begin{array}{l}\text { H4: Subjective norms } \\
\text { effect on decreasing } \\
\text { purchase intention of } \\
\text { organic vegetables }\end{array}$ & & \\
$\begin{array}{l}\text { H5: Perceived behavioral } \\
\text { control effect on } \\
\text { decreasing purchase } \\
\text { intention of organic } \\
\text { vegetables }\end{array}$ & 0,23 & 0,02 \\
$\begin{array}{l}\text { H6: Attitudes effect on } \\
\text { decreasing purchase } \\
\text { intention of organic } \\
\text { vegetables }\end{array}$ & & \\
\hline & 0,28 & $<0,01$ \\
& & \\
\end{tabular}

The results of hypothesis testing can be seen that at p-value less than 0.10 it can be said to be significantly weak, if the $p$-value is less than 0.05 it can be said to be significant and a p-value less than 0.01 can be said to be high significant (Solimun et al., 2017).

The price variable has an effect on the low purchasing attitude of organic vegetables. It can be seen that the $\mathrm{P}$ value is less than 0.01 (table 3 ), which is considered strong. These results are in line with research (Rodiger \& Hamm, 2015) which states that prices are an obstacle to attitudes and intentions of some consumers towards purchasing organic food. In this study, prices are described by several indicators, namely affordable prices and prices according to the benefits of the product. All indicators describe price influencing consumer attitudes towards organic vegetable products. So hypothesis one is accepted.

However, the second hypothesis shows that packaging has a negative effect on the low purchasing attitude of organic vegetables. For the $\mathrm{P}$ value of 0.07 , which is significantly weak (table 3 ), it means that the packaging factor has a weak effect on low attitudes. The results of this study are in accordance with research (Andari, 2016) that packaging does not have a strong effect on purchasing attitudes towards organic vegetables. In addition, research (Mutlu, 2007) includes packaging attributes that have no effect on purchasing organic products in developing countries. The packaging factor in this study is described by the indicator that the packaging looks attractive, neat and guaranteed to be safe, which all factors do not affect consumers. Therefore, hypothesis two is not accepted.

The quality variable can be seen that the $\mathrm{P}$ value is less than 0.01 (table 3 ), which is significantly strong, meaning that quality has a strong effect on low attitudes. This is supported by research (Andari, 2016) that the effect of quality on the attitudes desired by consumers is strongly related. Research (Oroian et al., 2017) states that packaging attributes have no effect on purchasing attitudes towards organic products. The attitude of purchasing organic products is influenced by quality, such as trust in healthier products(Naspetti $\&$ Zanoli, 2009). The quality factor of this research is illustrated by indicators such as freshness, cleanliness, and healthier products which influence consumers' decreasing purchasing attitude towards organic vegetables. Then hypothesis three is accepted.

Then the hypothesis is also accepted in the attitude variables, subjective norms and decreased perceiveds of behavioral control on purchasing intention of organic vegetables. Hypothesis four states that subjective norms have a positive effect on decreasing purchase intention of organic vegetables. Because table 3 shows that the $P$ value of 0.02 which is less than 0.05 can be said to be significant. The results of this study are in accordance with research (Susanti et al., 2018) showing subjective norm factors such as family members and the closest people who are able to influence purchase intention of organic vegetables. In a study (Aertsens et al., 2009) that consumers will make an intention to buy organic food by following the person closest to the consumer. Meanwhile, in this study, subjective norms such as family, friends and the media can affect the 
decreasing intention to buy organic vegetables. Therefore, hypothesis four is accepted.

In table 3 it can be seen that hypothesis five has a $\mathrm{P}$ value of less than 0.01 which is considered strong, meaning that the perceived behavioral control factor has a strong effect on decreasing purchase intention of organic vegetables. These results are consistent with research (Susanti et al., 2018) that the perceived behavior control with consideration of indicators such as making purchasing easier, the availability of organic vegetables and the ability to buy organic vegetables affects the intention to buy organic vegetables. In this study, the indicators used were the benefits of consuming organic vegetables, the ease of getting organic vegetables and the ability to buy organic vegetables. Then hypothesis five is accepted.

Hypothesis six states that attitudes have a positive effect on decreasing purchase intention of organic vegetables. In table 3 it can be seen that the $\mathrm{P}$ value is less than 0.01 which is considered strong, indicating that purchasing attitudes have a very strong influence on decreased purchase intention. This is supported by research (Rana \& Paul, 2017) that attitudes affect the purchase intention of organic food which has decreased supply and demand. Meanwhile, research (Muzayanah et al., 2015) states that attitudes have a strong influence on purchase intention of organic vegetables with four observed variables such as health, environment, attributes, and beliefs. However, the indicators used in this study are different, namely liking the presence of organic vegetables, being willing to buy organic vegetables and believing organic vegetables are safe for consumption. According to (Naspetti \& Zanoli, 2009) attitude attributes can use trust in product safety. All of these indicators support purchasing attitudes that have a strong influence on buying intention for organic vegetables. So hypothesis six is accepted.

The results of the discussion in this study are twofold, the first is the influence of factors on the low purchasing attitude of organic vegetables. Based on the results of testing the hypothesis (table 3 ), it shows that there are factors such as price and quality that have a strong influence on the low purchasing attitude of organic vegetables. Price has an effect of 0.40 on the low purchasing attitude of organic vegetables. This is because the price of organic vegetables is relatively expensive compared to inorganic vegetables. According to (Rodiger \& Hamm, 2015) the price of organic products is more expensive than conventional vegetables because of healthier organic product care.

The majority of consumers complained about the price of organic vegetables around Rp. 4,500 to Rp. 6,000 which is supported by less vegetable content than inorganic vegetables. There are consumers in the Kelurahan Sawojajar Malang City with incomes above Rp 2,500,000, they still have to think again about buying organic vegetables. According to (Pawlewicz, 2020) the price of expensive organic products causes a decrease in consumers to reach organic products. This causes consumers to dislike organic vegetables even though organic vegetables have more benefits and advantages than inorganic vegetables. According to (Paradiba et al., 2017) the price of organic vegetables is relatively expensive due to the limited sales of organic vegetables which are only available in the modern market so that consumers who buy come from the middle and upper class only.

Then the quality factor with indicators of freshness and cleanliness influenced the low purchasing attitude of organic vegetables by 0.39 . The fact in the research location is that there are still some organic vegetable products that are not fresh and not clean. Some consumers stated that the vegetables in the shop still had yellow leaves and the root vegetables still had some soil residue. Also, unsold vegetables that have been in the store for a long time are not sorted. According to (Naspetti \& Zanoli, 2009) the buying attitude of organic products can be influenced by the sales place that does not pay attention to the product and the condition of the product that is less attractive to consumers, thereby reducing buyers. This fact is supported by the educational background of consumers with more undergraduate degrees and working as housewives who really pay attention to these factors before buying organic vegetables. So quality factors such as freshness and cleanliness are very important assessments by consumers of purchasing decisions for organic vegetables (Anggiasari et al., 2016). This causes consumers to dislike and switch to buying inorganic vegetables.

One factor that does not affect the low purchasing attitude of organic vegetables is packaging. The majority of consumers at the Vegetable Shop in Sawojajar Village, Malang City do not pay attention to product packaging. However, some consumers complain that most of the packaging is made of plastic which has the potential to damage the environment. In research (Mutlu, 2007) that consumers also pay less attention to packaging, it causes a decline in purchasing attitudes for organic products and in fact organic products in Turkey, the most packaging materials made of plastic, should use organic materials. According to research (Andari, 2016), packaging does not affect the low purchasing attitude of organic vegetables because some consumers do not really pay attention to the shape or design of organic vegetable packaging. In addition, research (Oroian et al., 2017) shows that 
consumers pay less attention to packaging attributes, so it affects the decreasing purchasing attitude of organic products. So the packaging is not really paid attention by consumers in purchasing organic vegetables.

Second, the declining influence of factors on buying intention for organic vegetables. In this study, it is evident that the decreasing purchase intention of organic vegetables is strongly influenced by attitudes, subjective norms and perceived behavioral control.

Based on the results of the hypothesis (table 3 ), this purchasing attitude has the strongest and most significant effect on decreasing vegetable purchase intention. This is supported by the frequency of purchasing organic vegetables at the store only once a week. In fact, in the research area, the attitude of many consumers is that they like organic vegetables, believe they are safe to eat, but are not willing to buy organic vegetables. This attitude is also formed from the direct influence of the price and quality variables of organic vegetable products in this study. According to (Rodiger \& Hamm, 2015) that price and quality attributes have an effect on purchasing attitudes, if high prices indicate high product quality and vice versa low prices have a negative impact on product quality. The reason consumers have a decreased attitude towards purchasing organic vegetables is that there are factors that are not in accordance with consumer desires, such as the price is still relatively expensive, while the quality is still not fresh, not clean, and has less content. According to (Chrysanthini et al., 2018) the insignificant attitude towards buying intentions for organic vegetables is due to high prices, low availability and consumers not willing to buy organic vegetables.

The decreasing intention to buy organic vegetables is also caused by the influence of subjective norms. In fact, the majority of consumers have decreased purchase intention of organic vegetables due to the influence of communication and attitudes among organic vegetable consumers who switch to inorganic vegetables when shopping at the store. While a small proportion of consumers cultivate organic vegetables through the internet, their closest friends and neighbors have a small organic vegetable garden at home so they rarely buy organic vegetables at the vegetable shop. According to (Awwaliyah, 2013) person's intention to buy and consume organic food will be strong if consumers trust the people closest to them who give recommendations to buy organic food and vice versa. Research (Aertsens et al., 2009) also states that consumers will follow social norms that are usually carried out by consumers, such as consumers who are still lacking in purchasing intention of organic food. This causes the subjective norm affects the decreasing intention to buy organic vegetables.

After that, there is the influence of the perceived behavioral control factor which is proven to have a positive and significant effect on decreased purchase intention. In fact, the majority of consumers benefit a lot from consuming organic vegetables as some consumers buy organic vegetables as medicine. However, most consumers complain that the availability of spinach and mustard greens is low and quickly runs out. According to (Pawlewicz, 2020) the availability of various types of organic food is still decreasing, followed by high consumer demand. It can be seen that the type of vegetable that is often consumed by organic vegetable consumers is spinach. While vegetables are mostly sold, namely kale. This causes consumers to decide not to buy organic vegetables and to switch to buying inorganic vegetables. Because consumers see their family's appetite and the availability of organic vegetables in stores.

So the decreasing attitude and intention to buy organic vegetables is caused by several influencing factors such as high prices, lack of freshness and cleanliness, and the availability of products that often run out quickly which tends to make consumers unwilling to buy organic vegetables. This makes consumers decide not to buy organic vegetables and not prioritize buying organic vegetables.

\section{CONCLUSION}

The conclusion of this study, the low purchasing attitude of organic vegetables is influenced by the high price factor and the lack of freshness and cleanliness of the product. However, the packaging factor does not affect the low purchasing attitude of organic vegetables by 0.17 . The reason is that consumers do not pay attention to organic vegetable packaging and complain that most plastic packaging has the potential to damage the environment.

Then the decreasing intention to buy organic vegetables occurs due to attitude and communication factors between consumer friends when shopping for organic vegetables to buy inorganic vegetables and the availability of products that often run out quickly. So that this causes consumers to be unwilling to buy organic vegetables, not prioritizing organic vegetable choices and deciding not to buy organic vegetables.

Suggestions for local government, health agencies and related parties for organic vegetables to develop more organic vegetable cultivation in each region, more affordable prices for organic vegetables among the community and work together to invite people to follow a healthy 
lifestyle by choosing healthy foods for their families such as organic vegetables, in order to realize an educated and sustainable consumption behavior of organic vegetables.

Meanwhile, suggestions for organic vegetable producers can increase the availability of various types of organic vegetables that are in great demand by consumers so that it becomes an opportunity for producers to develop organic vegetable businesses among the community. In addition, suggestions for organic vegetable marketers pay more attention to packaging and product quality in order to increase sales of organic vegetables.

\section{REFERENCES}

Aertsens, J., Verbeke, W., Mondelaers, K., \& van Huylenbroeck, G. (2009). Personal Determinants of Organic Food Consumption. British Food Journal, 111(10), 1140-1167. https://doi.org/10.1108/00070700910992961

Alfian, N. (2016). Tingkat Penerapan Teknologi Budidaya Sayuran Organik oleh Petani Mitra CV. Tani Organik Merapi. FP UMY: Skripsi. https://doi.org/10.1017/CBO9781107415324. 004

Andari, N. M. (2016). Preferensi Konsumen Terhadap Sayuran Organik Di Super Indo Agung Yogyakarta. UMY: Skripsi.

Anggiasari, N. M., Yaktiworo, I., \& Endaryanto, T. (2016). Sikap dan Pengambilan Keputusan Pembelian Sayuran Organik Oleh Konsumen di Kota Bandar Lampung. JIIA, 4(4), 391397.

Awwaliyah, I. (2013). Pengetahuan, Sikap, dan Niat Beli Mahasiswa terhadap Makanan Organik: Pendekatan Theory of Planned Behavior. Repostitory IPB. IPB.

BPS, Kementerian Pertanian, BMKG, BNPB, LAPAN, WFP, \& FAO. (2017). Buletin Pemantauan Ketahanan Pangan indonesia Fokus Khusus: Tren konsumsi dan produksi buah dan sayur. German Humanitarian Assistance, 8(November), 1-24. Retrieved from

https://docs.wfp.org/api/documents/WFP0000024091/download/

Chrysanthini, B., Sumarwan, U., \& Rifin, A. (2018). Preferensi Konsumen terhadap Produk Sayuran Organik (Studi Kasus Konsumen UD Fabela-Myfarm) di Bogor Jawa Barat. Jurnal Manajemen Pengembangan Industri Kecil Menengah, 12(2), 151.

Hasan, H., Muis, A., \& Christoporus. (2019). Preferensi Konsumen Terhadap Pembelian Sayuran Organik di Kota Palu. Journal Agroland, 26(1), 39-48.
Liputan6. (2018). Konsumsi Sayuran dan Buah Masyarakat RI Masih di Bawah Standar FAO. Retrieved June 10, 2020, from https://www.liputan6.com/bisnis/read/348354 1/konsumsi-sayuran-dan-buah-masyarakat-rimasih-di-bawah-standar-fao

Mutlu, N. (2007). Consumer Attitude and Behaviour Towards Organic Food: CrossCultural Study of Turkey and Germany. Universitat Hohenheim.

Muzayanah, F. N., Suroso, A. I., \& Najib, M. (2015). Faktor-faktor yang Memengaruhi Resistensi Pembelian Pangan Organik dan Proses Pendidikan Konsumen. Jurnal Manajemen Dan Agribisnis, 12(3), 163-173.

Naspetti, S., \& Zanoli, R. (2009). Organic Food Quality And Safety Perception Throughout Europe. Journal of Food Products Marketing, 15(3), 249-266. https://doi.org/10.1080/10454440902908019

Oroian, C. F., Safirescu, C. O., Harun, R., Chiciudean, G. O., Arion, F. H., Muresan, I. C., \& Bordeanu, B. M. (2017). Consumers' Attitudes Towards Organic Products and Sustainable Development: A Case Study of Romania. Sustainability (Switzerland), 9(9). https://doi.org/10.3390/su9091559

Paradiba, D., Marhawati, M., \& Lamusa, A. (2017). Faktor-Faktor yang Mempengaruhi Permintaan Sayuran Organik di Kota Palu. EJ. Agrotekbis, 5(5), 564-571.

Pawlewicz, A. (2020). Change of price premiums trend for organic food products: The example of the polish egg market. Agriculture (Switzerland), $10(2)$. https://doi.org/10.3390/agriculture10020035

Rana, J., \& Paul, J. (2017). Consumer Behavior and Purchase Intention for Organic Food: A Review and Research Agenda. Journal of Retailing and Consumer Services, 38(May), 157-165. https://doi.org/10.1016/j.jretconser.2017.06.0 04

Rodiger, M., \& Hamm, U. (2015). How are organic food prices affecting consumer behaviour? A review. Food Quality and Preference, 43(November 2016), 10-20. https://doi.org/10.1016/j.foodqual.2015.02.00 2

Solimun, Rinaldo, F. A. A., \& Nurjannah. (2017). Metode Statistika Multivariat. Permodelan Persamaan Struktural (SEM). Pendekatan WarpPLS. Malang: UB Press.

Susanti, R., Muhaimin, A., \& Toiba, H. (2018). Analisis Faktor-Faktor yang Mempengaruhi Niat Pembelian Sayur Organik (Kasus Ibu Rumah Tangga di Kota Malang). Habitat, 29(3), 122-128. 